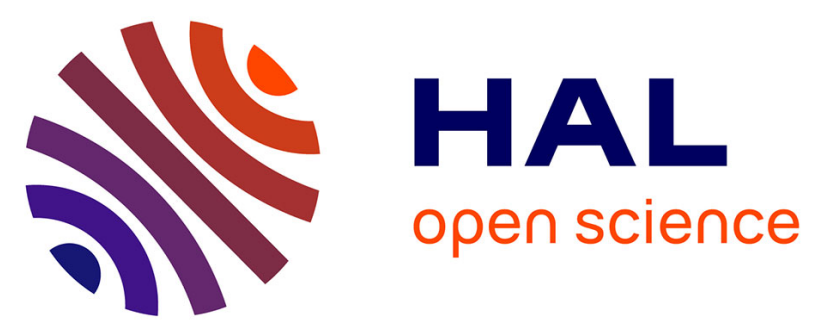

\title{
Effect of the sintering method on microstructure and thermal and mechanical properties of zirconium oxophosphate ceramics $\mathrm{Zr} 2 \mathrm{O}(\mathrm{PO} 4) 2$
}

Damien Bregiroux, Julie Cédelle, Isabelle Ranc, Céline Barreteau, Gustavo Mata Osoro, Gilles Wallez

\section{To cite this version:}

Damien Bregiroux, Julie Cédelle, Isabelle Ranc, Céline Barreteau, Gustavo Mata Osoro, et al.. Effect of the sintering method on microstructure and thermal and mechanical properties of zirconium oxophosphate ceramics Zr 2 O(PO 4 ) 2. Journal of Physics and Chemistry of Solids, 2017, 111, pp.304-310. 10.1016/j.jpcs.2017.08.008 . hal-01590780

\section{HAL Id: hal-01590780 \\ https://hal.sorbonne-universite.fr/hal-01590780}

Submitted on 20 Sep 2017

HAL is a multi-disciplinary open access archive for the deposit and dissemination of scientific research documents, whether they are published or not. The documents may come from teaching and research institutions in France or abroad, or from public or private research centers.
L'archive ouverte pluridisciplinaire HAL, est destinée au dépôt et à la diffusion de documents scientifiques de niveau recherche, publiés ou non, émanant des établissements d'enseignement et de recherche français ou étrangers, des laboratoires publics ou privés. 
Effect of the sintering method on microstructure and thermal and mechanical properties of zirconium oxophosphate ceramics $\mathrm{Zr}_{2} \mathrm{O}\left(\mathrm{PO}_{4}\right)_{2}$

Damien Bregiroux ${ }^{1, *}$, Julie Cedelle ${ }^{2}$, Isabelle Ranc ${ }^{2}$, Céline Barreteau ${ }^{3,4}$, Gustavo Mata Osoro $^{3,4}$ and Gilles Wallez $z^{3,4}$

${ }^{1}$ Sorbonne Universités, UPMC Univ Paris 06, CNRS, Collège de France, Laboratoire de Chimie de la Matière Condensée de Paris, 4 place Jussieu, 75005 Paris, France

${ }^{2}$ Laboratoire LEME, UPL, Univ Paris Nanterre, 50 rue de Sèvres, 92410 Ville d'Avray, France

${ }^{3}$ Chimie Paris-Tech, PSL Research University, Institut de Recherche de Chimie-Paris, 11 Rue Pierre et Marie Curie, 75005, Paris, France

${ }^{4}$ Sorbonne Universités, UPMC, 4 place Jussieu, 75005 Paris, France

* Corresponding author. Tel.: + 33144275679

E-mail address: damien.bregiroux @upmc.fr (D. Bregiroux)

\begin{abstract}
Due to an ultra-low thermal expansion, $\mathrm{Zr}_{2} \mathrm{O}\left(\mathrm{PO}_{4}\right)_{2}$ could find many applications as a thermal shock resistant material. To this end, ceramic processing is a key step in order to reach best properties. In this work, $\mathrm{Zr}_{2} \mathrm{O}\left(\mathrm{PO}_{4}\right)_{2}$ was sintered by conventional sintering and by the spark plasma sintering technique (SPS) with and without additive. Samples made by conventional sintering with $\mathrm{ZnO}$ as sintering aid have a maximum relative density of around $92 \%$. Microstructure is composed of large grains and microcracks can be observed. When doped
\end{abstract}


with 5 wt. \% of $\mathrm{MgO}$, samples can be densified by SPS up to $99.6 \%$ of the relative density and the grain size maintained between 0.5 and $1.5 \mu \mathrm{m}$. Thermal conductivity and Vickers microhardness were investigated as a function of the microstructure. Best values were obtained for the ceramic doped with $5 \mathrm{wt} . \% \mathrm{MgO}$ and sintered by SPS, thanks to a fine microstructure and a small amount of residual microcracks.

\section{Keywords}
A. Ceramics, Oxides
D. Mechanical properties, Thermal conductivity, Thermal expansion,

\section{Introduction}

During the last decades, many efforts have been made to develop ceramics for utilization under thermal shock conditions [1]. Among them, composites present very high properties but their production cost is generally high [2]. In the case of bulk materials, reducing the thermal expansion coefficient is one of the keys to improve the thermal shock resistance [3]. Amongst the usual refractories, the chemical bond that presents the lowest thermal expansion is the carbon-carbon bond in graphite (around $1.010^{-6} \mathrm{~K}^{-1}$ ) [4], but some oxides can also exhibit low or negative thermal expansion (L/NTE). This stems from several structural mechanisms that affect the crystal cell $[5,6]$, such as the rocking of vertices-connected polyhedra (e.g. silica, $\left.\mathrm{Zr}\left(\mathrm{WO}_{4}\right)_{2}\right)$, the increase of symmetry (e.g. $\left.\mathrm{PbTiO}_{3}\right)$, the coupling of negative expansion with a strong positive uniaxial one (e.g. $\left.\mathrm{NaZr}_{2}\left(\mathrm{PO}_{4}\right)_{3}\right)$. In 2003 and 2008, Wallez et al. cleared up the atomic mechanism responsible for the low mean linear thermal expansion of the two forms $\alpha$ and $\beta-\mathrm{Zr}_{2} \mathrm{O}\left(\mathrm{PO}_{4}\right)_{2}\left(2.610^{-6} \mathrm{~K}^{-1}\right.$ and $1.610^{-6} \mathrm{~K}^{-1}$, respectively) [7,8]. The thermal expansion of the $\alpha$ form can be explained by a mechanism which involves a classical ring deformation and the rocking of bridging oxygen atoms, but this phase, which turns irreversibly into the $\beta$-form 
between 1100 and $1250{ }^{\circ} \mathrm{C}$, is of secondary interest $[9,10]$. The low thermal expansion of the $\beta$ form is more atypical and can be explained by a dual thermal contraction mechanism based on cation-cation Coulombic repulsion that leads to the resorption of cavities of the structure and a rocking effect of the $\mathrm{Zr}-\mathrm{O}-\mathrm{Zr}$ bonds. $\beta-\mathrm{Zr}_{2} \mathrm{O}\left(\mathrm{PO}_{4}\right)_{2}$ exhibits a thermal expansion anisotropy (3.9, -3.6 and $4.310^{-6} \mathrm{~K}^{-1}$ for $\alpha_{a}, \alpha_{b}$ and $\alpha_{c}$, respectively). As it is a cheap, easy to synthesize, environmental-friendly, stable to around $1600{ }^{\circ} \mathrm{C}$ and chemically inert material, $\beta$ $\mathrm{Zr}_{2} \mathrm{O}\left(\mathrm{PO}_{4}\right)_{2}$ is a very good candidate for thermal applications. Moreover, its electrical conductivity and its dielectric permittivity are very low, thus allowing its use for the making of radomes for missiles or rockets [11]. Paradoxically, $\beta-\mathrm{Zr}_{2} \mathrm{O}\left(\mathrm{PO}_{4}\right)_{2}$ remains far less studied by the academic community than the other low thermal expansion materials. In a previous paper, we showed that the only isovalent cations likely to substitute for $\mathrm{Zr}^{\mathrm{IV}}$ or $\mathrm{P}^{\mathrm{V}}$ are either harmful, or unstable, chemically or thermally speaking [12]. Furthermore, aliovalent substitutions are forbidden by the crystal structure. The sintering behavior of $\beta-\mathrm{Zr}_{2} \mathrm{O}\left(\mathrm{PO}_{4}\right)_{2}$ was studied by Yamai et al. in the 80's $[13,14]$. According to their work, it seems that this compound is impossible to sinter by conventional techniques without additive. Sintering can be promoted by the presence of a liquid phase induced by the addition of a metal oxide $M O$ $(M=\mathrm{Zn}$ or $\mathrm{Mg})$, that reacts at high temperature with $\mathrm{Zr}_{2} \mathrm{O}\left(\mathrm{PO}_{4}\right)_{2}$ to form $M_{3}\left(\mathrm{PO}_{4}\right)_{2}$. Nevertheless, the presence of residual amorphous phase at grain boundaries could lead to a decrease of final properties. Moreover, the presence of a liquid phase enhances grain growth, resulting in the development of microcracks due to the anisotropy of thermal expansion in the crystal cell. Apart from the use of additives, sintering should be enhanced by decreasing the grain size of the starting powder, or by using pressure-assisted sintering techniques, such as Hot Pressing (HP) or Spark Plasma Sintering (SPS). These techniques are well known to be efficient for the elaboration of dense ceramics with limited grain growth [15], and therefore with increased thermal properties $[16,17]$. 
The objective of the present work is to make $\beta-\mathrm{Zr}_{2} \mathrm{O}\left(\mathrm{PO}_{4}\right)_{2}$ ceramics with well-controlled density and microstructure by using the SPS technique on attrition milled powders with or without additive. Thermal conductivity of sintered ceramics is investigated in relation with their microstructure. Results are compared with those obtained by conventional sintering $\beta$ $\mathrm{Zr}_{2} \mathrm{O}\left(\mathrm{PO}_{4}\right)_{2}$ with $\mathrm{ZnO}$ as a sintering aid.

\section{Material and methods}

\subsection{Samples preparation}

$\mathrm{Zr}_{2} \mathrm{O}\left(\mathrm{PO}_{4}\right)_{2}$ powders were made by precipitation from $\mathrm{NH}_{4} \mathrm{H}_{2} \mathrm{PO}_{4}$ (Sigma-Aldrich, 98.5\%), $\mathrm{ZrOCl}_{2}, 8 \mathrm{H}_{2} \mathrm{O}$ (Sigma-Aldrich, 99.5\%) in stoichiometric proportions. The precursors were dissolved in distilled water and mixed at $70{ }^{\circ} \mathrm{C}$ to obtain a gel. We observed that remaining chlorides replace the phosphates as counteranions and provoke their loss and the formation of $\mathrm{ZrO}_{2}$ during annealing. Consequently, the gels were washed and separated by centrifugation several times until elimination of $\mathrm{Cl}^{-}$anions from the supernatant $\left(\mathrm{AgNO}_{3}\right.$ test). Phase purity was checked by X-ray diffraction measurements in a Panalytical X'Pert Pro diffractometer $\left(45 \mathrm{kV}, 40 \mathrm{~mA}, \lambda \mathrm{K}_{\alpha 1}(\mathrm{Cu})=1.5405 \AA\right.$ A/forward $\left.\mathrm{Ge}(111)\right)$. The pure $\beta$ form of $\mathrm{Zr}_{2} \mathrm{O}\left(\mathrm{PO}_{4}\right)_{2}$ was obtained by slowly annealing this precipitate in air at $1350{ }^{\circ} \mathrm{C}$ for $5 \mathrm{~h}$. Thermal behavior of the as-precipitated powder was analyzed under air flow on a DTA Setaram apparatus, at a heating rate of $2^{\circ} \mathrm{C} / \mathrm{min}$ in a Pt crucible. Attrition ground powder was obtained by grinding for $5 \mathrm{~h}$ in water, $70 \mathrm{~g}$ of $\beta-\mathrm{Zr}_{2} \mathrm{O}\left(\mathrm{PO}_{4}\right)_{2}$ powder in a $750 \mathrm{~cm}^{3}$ teflon jar with $700 \mathrm{~g}$ of a $50 / 50$ mixture of 1 and $2 \mathrm{~mm}$ zirconia beads. The blades' revolution speed was $450 \mathrm{rpm}$. Specific surface area of the raw and attrition-milled powders was measured by the BET method in $\mathrm{N}_{2}$ with a Belsorp-Max apparatus. Attrition-ground powder was then uniaxially pressed using a pressure of $50 \mathrm{MPa}$ into pellets of $13 \mathrm{~mm}$ in diameter. For some samples, $\mathrm{ZnO}$ or $\mathrm{MgO}$ was also added as a sintering aid in the desired amount. The green density of samples, determined 
by geometrical measurements, is close to $53 \%$ of the theoretical one. Increasing the uniaxial pressure in order to reach higher green densities provokes interfacial cracks between density regions in the green body, which enlarge during sintering. Conventional sintering was performed in air with a heating and cooling rates of $10^{\circ} \mathrm{C} \cdot \mathrm{min}^{-1}$. Attrition-milled $\beta$ $\mathrm{Zr}_{2} \mathrm{O}\left(\mathrm{PO}_{4}\right)_{2}$ powder was also sintered with and without additive by spark plasma sintering (Dr Sinter-Lab SPS-515S, SPS Sintex Inc.) in an 8 or $15 \mathrm{~mm}$ diameter graphite die with a constant applied pressure of $100 \mathrm{MPa}$. The heating rate was fixed to $100{ }^{\circ} \mathrm{C} \cdot \mathrm{min}^{-1}$. The cooling rate was around $50{ }^{\circ} \mathrm{C} \cdot \mathrm{min}^{-1}$. Each SPS experiment was performed twice in order to check the reproducibility. All the SPS pellets were annealed in air at high temperature (depending on the sintering temperature and on the additive used for sintering) for several hours in order to eliminate the defects induced by the reducing conditions generated by the carbon of the graphite die. Bulk density of the sintered pieces was determined by the Archimedes method in water. The relative density of each specimen was calculated as the quotient of bulk density to theoretical density $\left(\mathrm{d}_{\mathrm{th}}=3.80 \mathrm{~g} \cdot \mathrm{cm}^{-3}\right)$. Standard deviation, estimated from repeated experiments was around $0.75 \%$. Microstructures of the sintered pellets were observed upon thermally etched samples SEM micrographs, performed on a SU70 Hitachi SEM-FEG.

\subsection{Thermal and mechanical properties}

The thermal conductivity was measured by the transient plane source (TPS) technique, with a TPS 2500 Hot Disk thermal analyzer (accuracy of around 2\%). This is an unsteady state method, based on the analysis of the thermal response of the sample surface to a heat rate supplied by the sensor. Indeed, the surface temperature increase strongly depends on the thermal properties - conductivity, diffusivity and specific heat. The sensor is placed between two identical samples. Heating is achieved by the passing an electrical current through the 
sensor and the surface temperature is measured from the electrical resistance variation of the same sensor. The detailed thermal model was explained by Gustafsson and He $[18,19]$, assuming the sample is a semi-infinite region. This assumption avoids taking into account the convective and radiation boundary conditions.

Average and axial thermal conductivities have been measured from room temperature up to $650{ }^{\circ} \mathrm{C}$ with sensors made of a double spiral of thin nickel wire coated by mica for electrical insulation. Temperature stability was $0.2^{\circ} \mathrm{C}$.

Specific heat capacity measurement $(\mathrm{Cp})$ was realized both on the powder and on bulk material. The first measurement, using Differential Scanning Calorimetry technique (SETARAM) on pure $\mu \mathrm{m}$-sized zirconia phosphate powder $\left(\mathrm{Zr}_{2} \mathrm{O}\left(\mathrm{PO}_{4}\right)_{2}(\mathrm{~m}=80.7 \mathrm{mg})\right.$ on temperature range $\left[0-50{ }^{\circ} \mathrm{C}\right]$ indicated a mean value of $\mathrm{Cp}=0.57 \pm 0.06 \mathrm{~J} . \mathrm{g}^{-1} \cdot{ }^{\circ} \mathrm{C}^{-1}$ at room temperature. Second measurements were obtained using Hot Disk equipment and specific heat capacity estimation was realized on SPS pure zirconia phosphate pellets.

Resulting mean value is $0.59 \pm 0.08 \mathrm{J.g}^{-1} \cdot{ }^{\circ} \mathrm{C}^{-1}$, which is in very good accordance with the result obtained from the DSC experiment.

\section{Results and discussion}

\subsection{Synthesis and thermal behavior of $\mathrm{Zr}_{2} \mathrm{O}\left(\mathrm{PO}_{4}\right)_{2}$ powders}

The obtained precipitate, dried at $110^{\circ} \mathrm{C}$, consisted of an amorphous powder with a very high specific surface area $\left(335 \mathrm{~m}^{2} \cdot \mathrm{g}^{-1}\right)$ (Fig. 1.). 


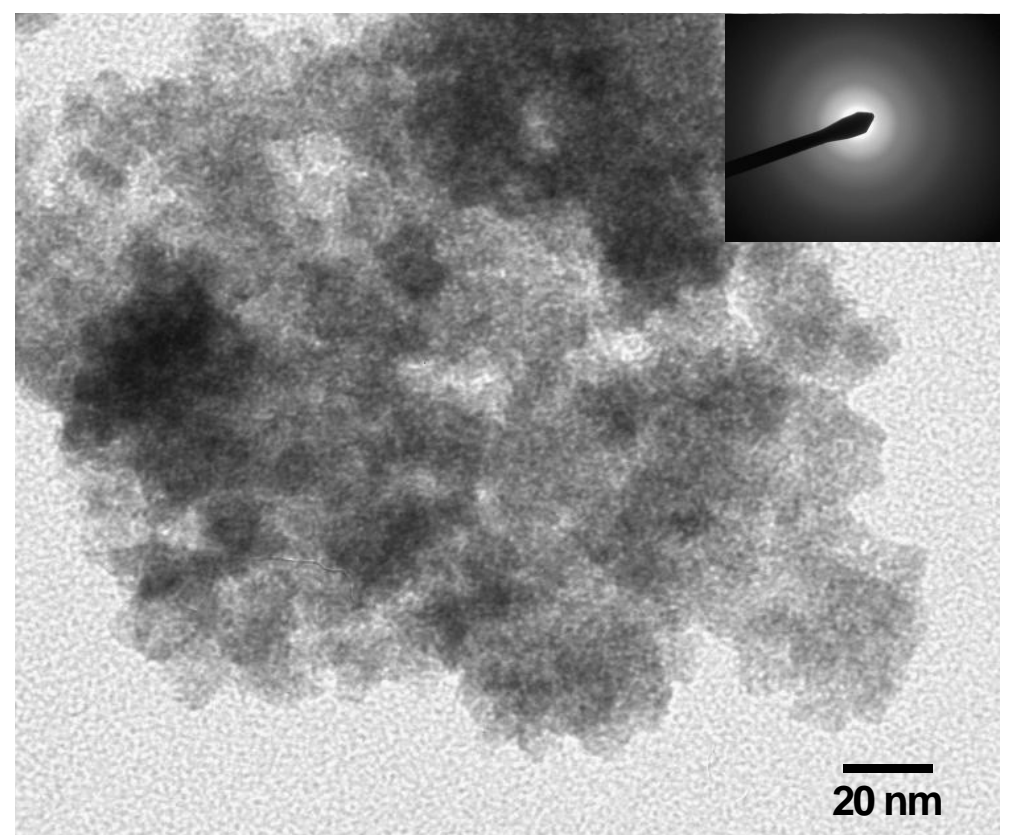

Fig. 1. TEM micrograph of the raw precipitate. Inset is the selected-area electron patterns (SAED).

DTA/TG analysis highlights that dehydration occurs around $100{ }^{\circ} \mathrm{C}$, evidencing that water is weakly bounded to the powder (adsorbed water) (Fig. 2.). Crystallization occurs around $1000{ }^{\circ} \mathrm{C}$. As already mentioned, $\mathrm{Zr}_{2} \mathrm{O}\left(\mathrm{PO}_{4}\right)_{2}$ crystallizes in its alpha form and turns gradually and irreversibly into the $\beta$-form between 1100 and $1250^{\circ} \mathrm{C}$. XRD analyses confirm the amorphous nature of the raw precipitate (Fig 3.). After calcination at $1400{ }^{\circ} \mathrm{C}$, the powder is well crystallized and mainly single phased (orthorhombic $\beta$-form, PDF ${ }^{\circ}$ 00-070-0888), with some traces of $\mathrm{Zr}_{2} \mathrm{P}_{2} \mathrm{O}_{7}$ as secondary phase. 


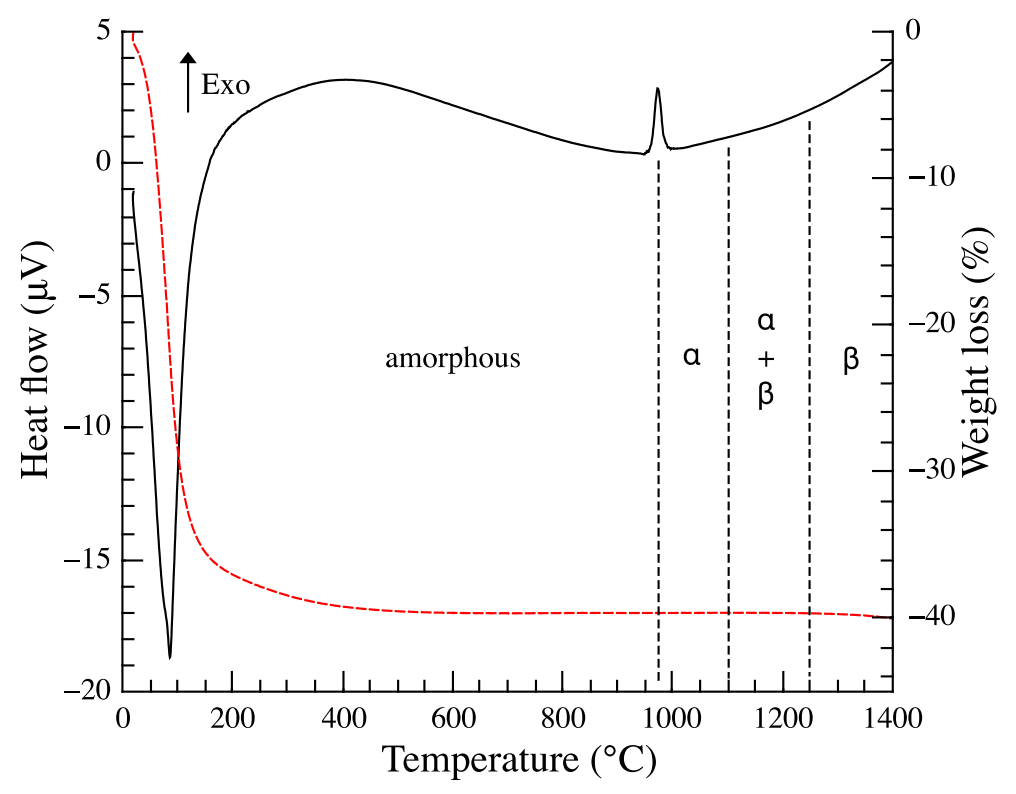

Fig. 2. DTA/TG plot of the as-synthesized powder (solid line: DTA signal, dotted line: weight loss).

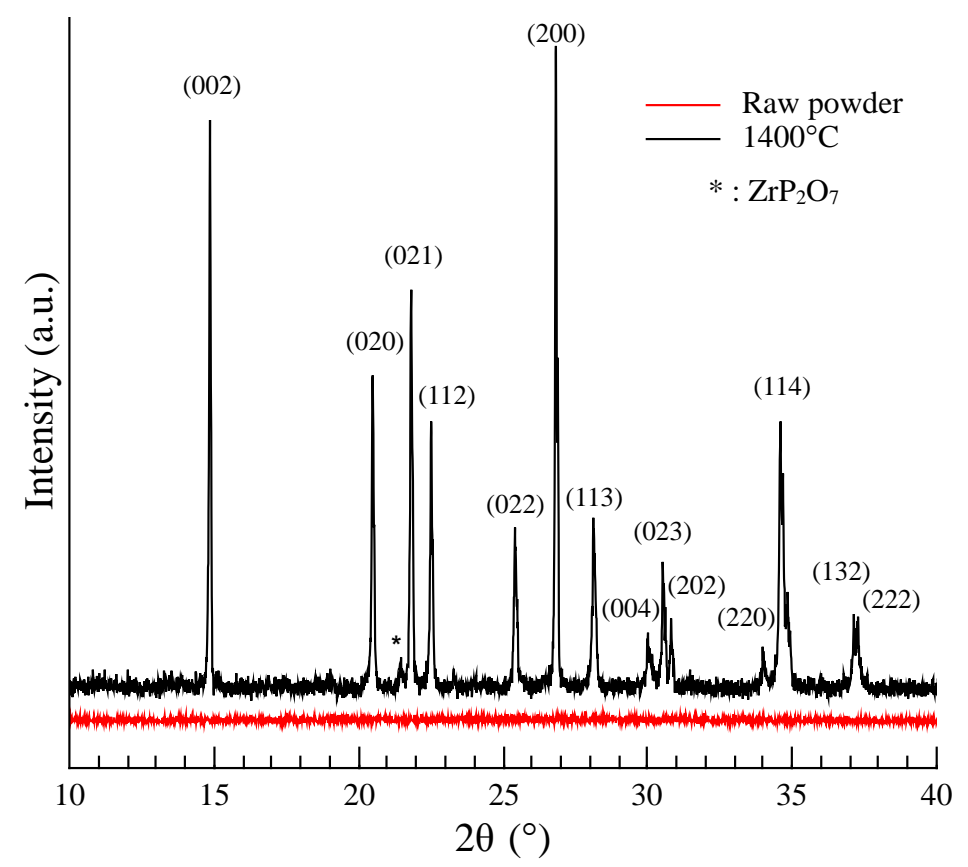

Fig. 3. XRD pattern of the synthesized powder, before and after calcination at $1400{ }^{\circ} \mathrm{C}$ (indexed peaks correspond to the $\beta-\mathrm{Zr}_{2} \mathrm{O}\left(\mathrm{PO}_{4}\right)_{2}$ structure, $\mathrm{PDF} \mathrm{n}^{\circ}$ 00-070-0888). 
During heating, specific surface area decreases very rapidly (Fig. 4.), probably through viscous sintering mechanism, so that it was not possible to obtain crystallized powder (neither alpha nor beta) with small and un-agglomerated grains. The resulting powder was then made of large hard agglomerates and exhibited a specific surface area of less than $1 \mathrm{~m}^{2} \cdot \mathrm{g}^{-1}$ (Fig. 5). Consequently, a grinding step is required before sintering (see Section 3.), resulting in powder with mean grain size of around $1 \mu \mathrm{m}$ (Fig. 5.) and specific surface area of $11 \mathrm{~m}^{2} \cdot \mathrm{g}^{-1}$. Note that neither $\mathrm{ZrP}_{2} \mathrm{O}_{7}$ nor $\mathrm{ZrO}_{2}$, that occur through thermal decomposition of the compound, were observed by XRD. Because the calcined/milled powder is crystallized, grain coarsening kinetics during heating is much lower than that of the amorphous raw powder. Therefore, the decrease of specific surface area is shifted toward the higher temperature (Fig. 4.).

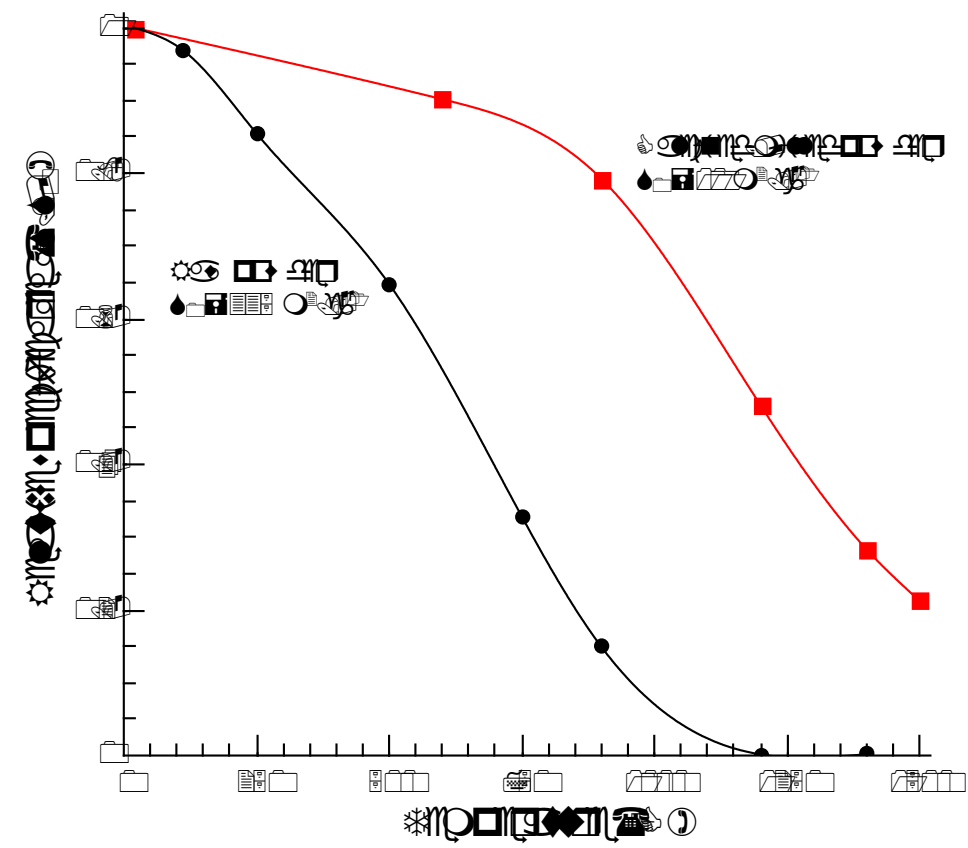

Fig. 4. Comparison between the specific surface area evolution of the as-synthesized and the calcined/milled powders. 

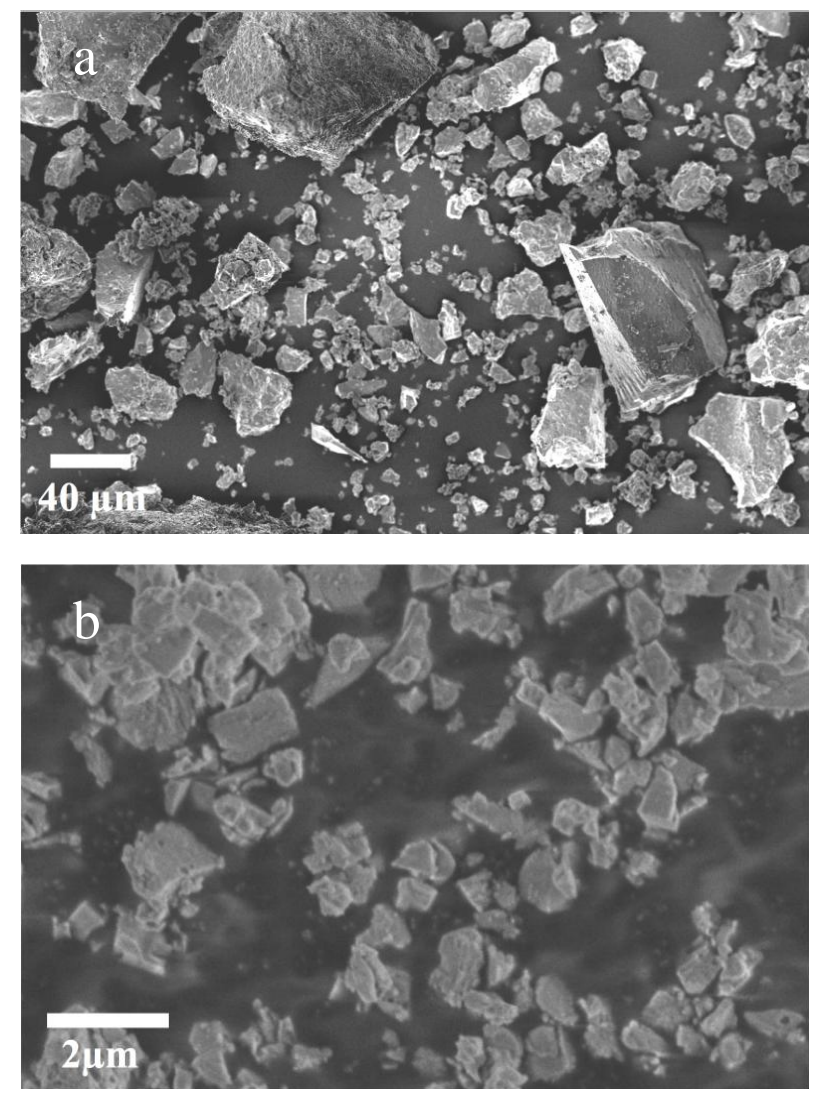

Fig. 5. Particles morphology of the powder calcined at $1400{ }^{\circ} \mathrm{C}$ before (a) and after attrition milling (b).

\subsection{Sintering}

\subsubsection{Conventional sintering}

Based on the results of Yamai et al. [13], $\mathrm{Zr}_{2} \mathrm{O}\left(\mathrm{PO}_{4}\right)_{2}$ ceramics were prepared by conventional sintering with $\mathrm{ZnO}$ as sintering additive. Fig. 6. shows that the optimal doping level is around 5 wt. $\%$. 


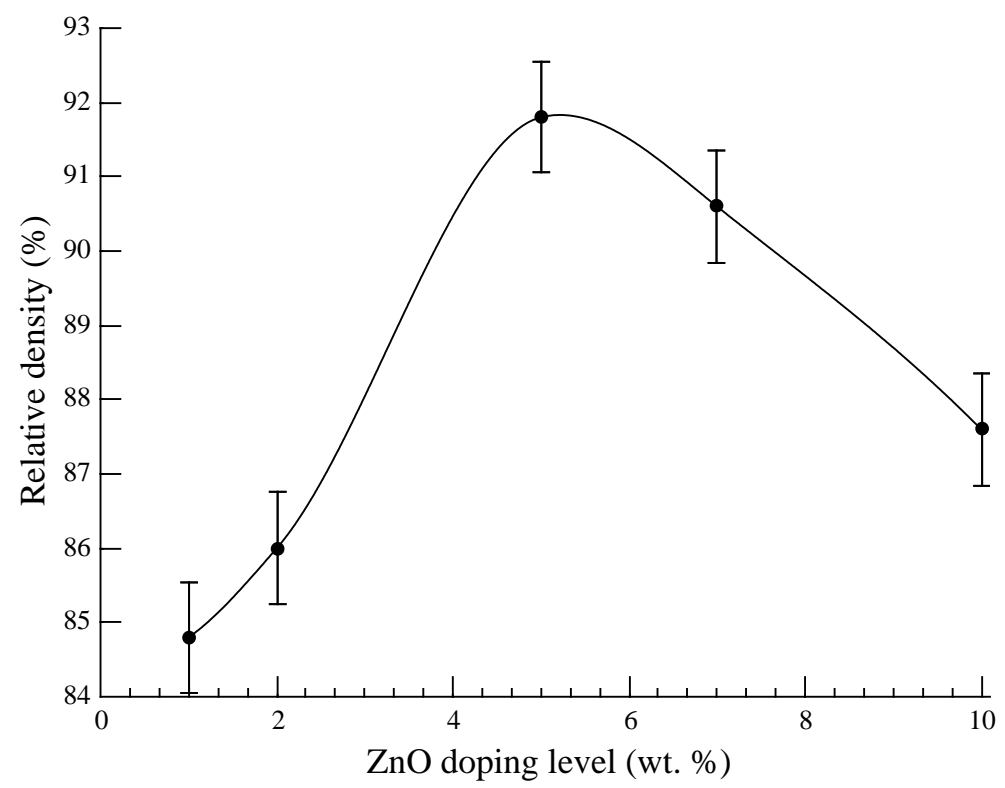

Fig. 6. Effect of $\mathrm{ZnO}$ content on the relative density of $\mathrm{Zr}_{2} \mathrm{O}\left(\mathrm{PO}_{4}\right)_{2}$ sintered at $1400{ }^{\circ} \mathrm{C}-2 \mathrm{~h}$

Fig. 7 shows the coupling analysis by dilatometry and DTA of an attrition-milled $\mathrm{Zr}_{2} \mathrm{O}\left(\mathrm{PO}_{4}\right)_{2}$ compact doped with $5 \mathrm{wt} . \% \mathrm{ZnO}$. One can observe, concomitantly of an endothermic peak on the DTA signal, an increase of the densification kinetic at $1050{ }^{\circ} \mathrm{C}$. This temperature corresponds to the melting of a secondary phase, previously identified by Yamai et al. as $\mathrm{Zn}_{3}\left(\mathrm{PO}_{4}\right)_{2}$ (melting point of $\mathrm{Zn}_{3}\left(\mathrm{PO}_{4}\right)_{2}: 1040{ }^{\circ} \mathrm{C}$ ) [13]. 

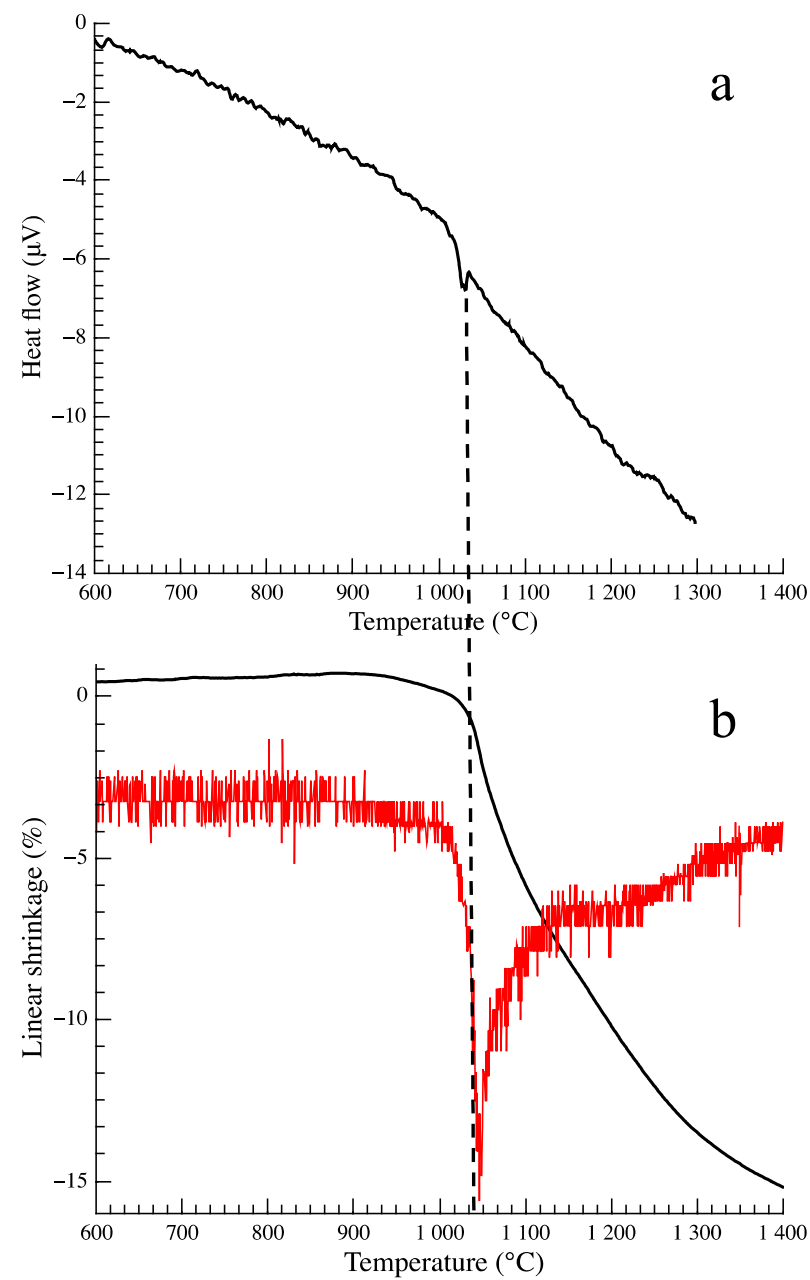

Fig. 7. Differential thermal analysis (a) and dilatometry (b, the red curve is the derivative of the black one) of an attrition-milled $\mathrm{Zr}_{2} \mathrm{O}\left(\mathrm{PO}_{4}\right)_{2}$ compact with 5 wt.\% $\mathrm{ZnO}$.

Isothermal study of the densification behavior of $\mathrm{Zr}_{2} \mathrm{O}\left(\mathrm{PO}_{4}\right)_{2}$ confirms that the ceramics do not densify at all without additive (Fig. 8). Note that this observation is valid whatever the sintering temperature. When doped with 5 wt. \% $\mathrm{ZnO}$, samples can be densified up to $92.5 \%$ of the theoretical density at temperature between 1250 and $1300{ }^{\circ} \mathrm{C}$. An increase of the sintering temperature does not improve the densification. On the contrary, one can observe a decrease of the final relative density, probably due to the decomposition of the secondary phase $\mathrm{Zn}_{3}\left(\mathrm{PO}_{4}\right)_{2}$. 


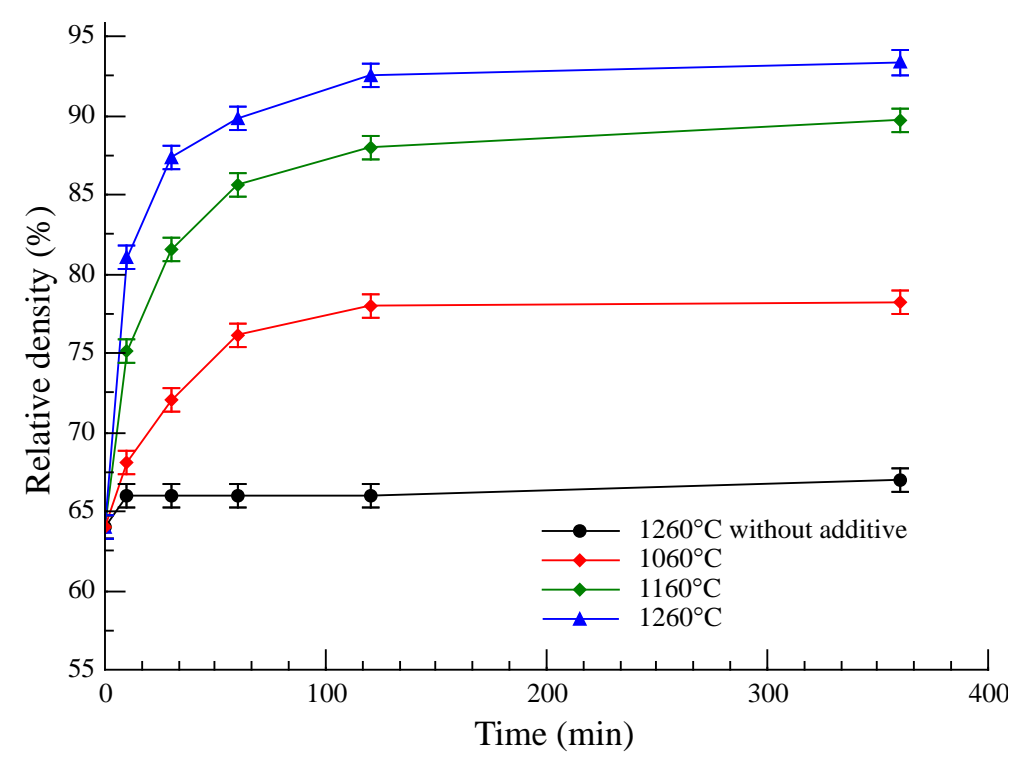

Fig. 8. Effect of temperature on the densification kinetic of $\mathrm{Zr}_{2} \mathrm{O}\left(\mathrm{PO}_{4}\right)_{2}$ doped with 5 wt. \% $\mathrm{ZnO}$

As commonly observed in the case of liquid phase sintering, $\mathrm{Zr}_{2} \mathrm{O}\left(\mathrm{PO}_{4}\right)_{2}$ ceramics doped with 5 wt. $\%$ after sintering at $1260{ }^{\circ} \mathrm{C}-1 \mathrm{~h}$ exhibit round-shaped grains (Fig. 9-a). Grains size ranges from 2 to $20 \mu \mathrm{m}$. The secondary phase $\mathrm{Zn}_{3}\left(\mathrm{PO}_{4}\right)_{2}$ can easily be observed on the fracture (Fig. 9-b). Pores can be observed in the $\mathrm{Zn}_{3}\left(\mathrm{PO}_{4}\right)_{2}$ phase, probably due to the beginning of its thermal decomposition. Note that failure mechanism is a combination of intergranular and transgranular fracture, suggesting poor mechanical properties. This can be explained by the presence of huge grains in the microstructure. In materials having high thermal expansion anisotropy, microcracking can occurs when grain size exceeds a value called transition grain size. According to Yamai and Ota [13], the transition grain size in $\mathrm{Zr}_{2} \mathrm{O}\left(\mathrm{PO}_{4}\right)_{2}$ is around $7 \mu \mathrm{m}$. Thus, since grain size is much higher than this value, this sintering process is not suitable for the fabrication of thermal shock resistant ceramics. 

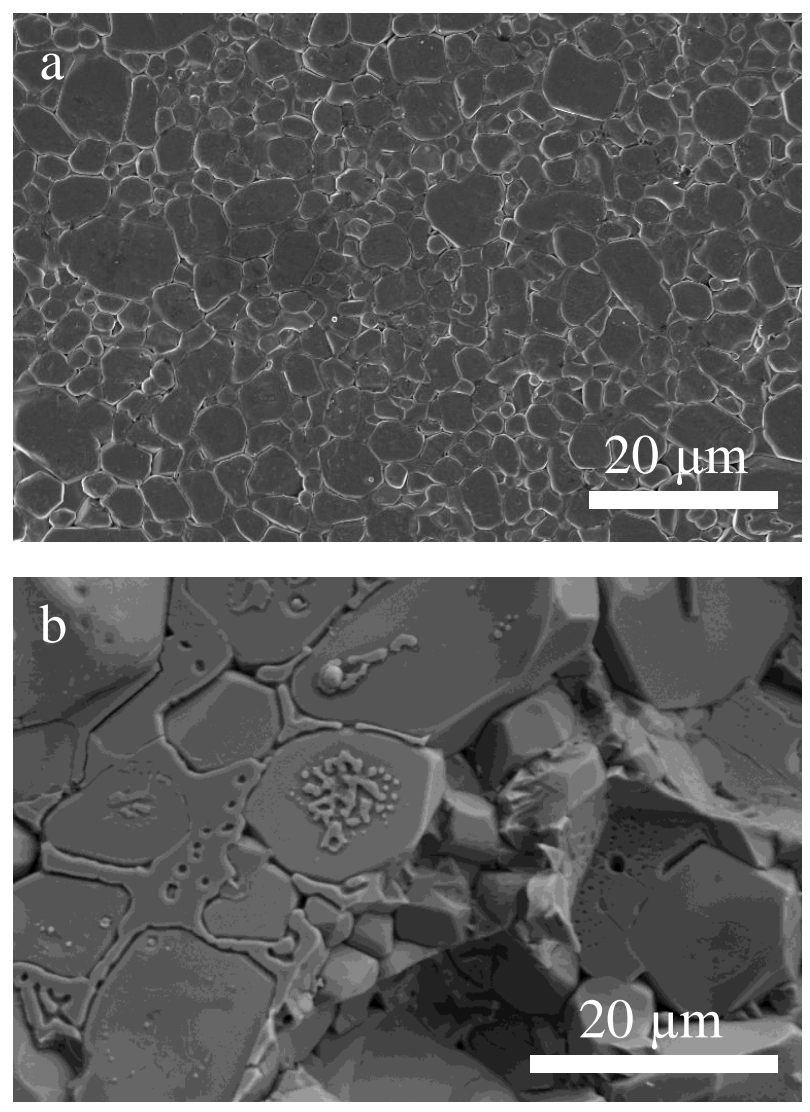

Fig. 9. SEM observation of the microstructure of $\mathrm{Zr}_{2} \mathrm{O}\left(\mathrm{PO}_{4}\right)_{2}$ ceramic doped with 5 wt. \% $\mathrm{ZnO}$ and sintered at $1260{ }^{\circ} \mathrm{C}-1 \mathrm{~h}$ (thermally etched surface (a), fracture(b)).

\subsubsection{Spark Plasma Sintering}

A thermal shock resistant material should exhibit both high thermal conductivity and good mechanical properties. For a given material, this implies to reach high relative density while maintaining a fine microstructure. As mentioned earlier, for materials with high thermal expansion anisotropy, grains size should be kept below the transition grain size (around $7 \mu \mathrm{m}$ for $\left.\mathrm{Zr}_{2} \mathrm{O}\left(\mathrm{PO}_{4}\right)_{2}\right)$. Spark Plasma Sintering is a technique that allows densifying materials while maintaining a fine microstructure [15].

Linear shrinkage of attrition-milled $\mathrm{Zr}_{2} \mathrm{O}\left(\mathrm{PO}_{4}\right)_{2}$ powder without additive is plotted on Fig. 10. Densification starts around $1200{ }^{\circ} \mathrm{C}$ but is not finished at $1450{ }^{\circ} \mathrm{C}$. At higher temperature, the powder starts to decompose, as proved by the presence of a red deposit on the cold surface of 
the SPS furnace after the experiments. According to literature, $\mathrm{Zr}_{2} \mathrm{O}\left(\mathrm{PO}_{4}\right)_{2}$ should be stable up to $1600{ }^{\circ} \mathrm{C}$ [20], but in the presence of graphite, a reduction of phosphorus should start at $1450{ }^{\circ} \mathrm{C}$ so that it is impossible to sinter at higher temperature. Final relative density is $77.8 \%$ (Table 1). This first result shows that fully dense $\mathrm{Zr}_{2} \mathrm{O}\left(\mathrm{PO}_{4}\right)_{2}$ ceramics cannot be obtained from the pure compound, even by SPS technique. The use of sintering additives is thus required, as in the case of conventional sintering. Based on the work of Yamai et al. [13], $\mathrm{ZnO}$ and $\mathrm{MgO}$ were tested as sintering aids. Fig. 10 shows that linear shrinkage reaches a plateau in both cases, at 1000 and $1200{ }^{\circ} \mathrm{C}$, respectively. This improvement of densification behavior can be explained by the formation of a secondary phase $\left(M_{3}\left(\mathrm{PO}_{4}\right)_{2}, M: \mathrm{Zn}\right.$ or $\left.\mathrm{Mg}\right)$ that melts at low temperature $\left(1040\right.$ and $1184^{\circ} \mathrm{C}$, respectively), thus enhancing densification by a liquid phase sintering mechanism.

Resulting pellets were deeply black, due to the carbon contamination and the reducing atmosphere generated by the graphite die at high temperature. White pellets can be obtained without modification of the relative density after annealing treatment under air at $1100{ }^{\circ} \mathrm{C}$ for at least $20 \mathrm{~h}$ only for $\mathrm{Mg}$ doped samples. For $\mathrm{Zn}$ doped samples, an important swelling was observed when annealing treatment was performed at temperature higher than $1000{ }^{\circ} \mathrm{C}$. Annealing below $1000{ }^{\circ} \mathrm{C}$ was inefficient. This phenomenon is not explained. 


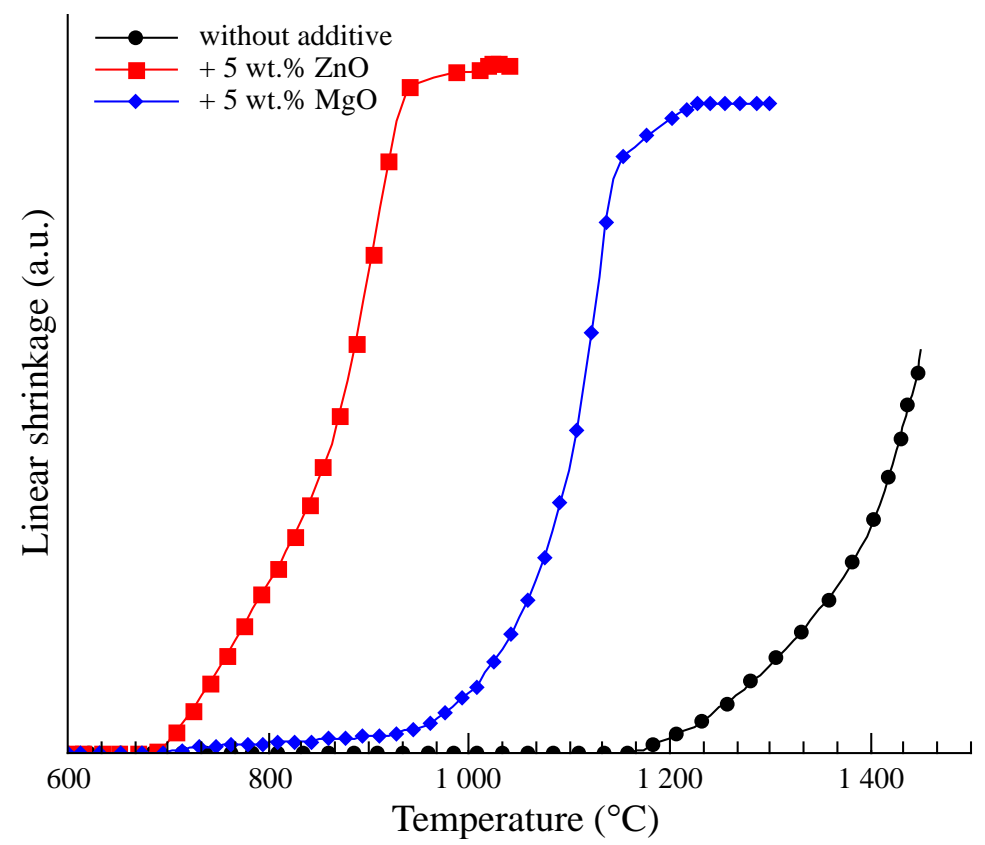

Fig. 10. Effect of the additive nature on SPS sintering of attrition milled $\mathrm{Zr}_{2} \mathrm{O}\left(\mathrm{PO}_{4}\right)_{2}$ powder

Consequently, only $\mathrm{MgO}$ was used as sintering additive for the rest of the study. Fig. 11 shows the relative shrinkage of attrition milled $\mathrm{Zr}_{2} \mathrm{O}\left(\mathrm{PO}_{4}\right)_{2}$ powder sintered with different amounts of $\mathrm{MgO}$. At $1300{ }^{\circ} \mathrm{C}$, full densification is reached only for $5 \mathrm{wt} . \%$ of $\mathrm{MgO}$ (Table 1 ).

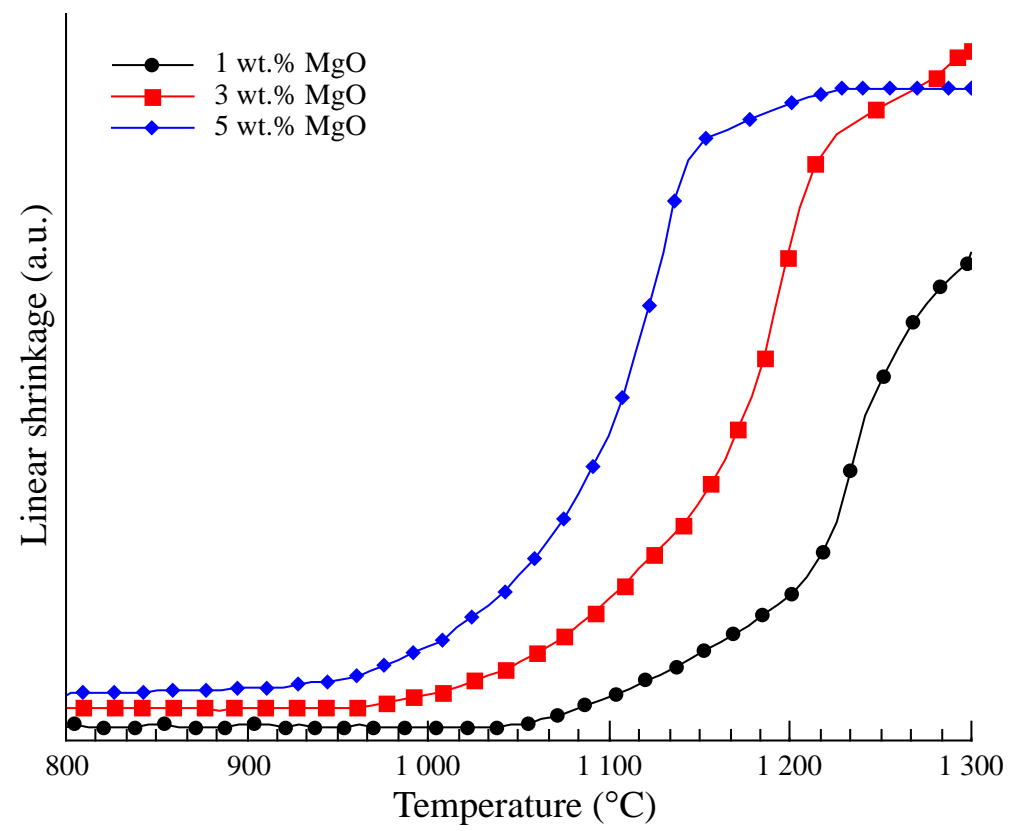

Fig. 11. Effect of $\mathrm{MgO}$ amount on SPS sintering of attrition milled $\mathrm{Zr}_{2} \mathrm{O}\left(\mathrm{PO}_{4}\right)_{2}$ powder 
SEM analyses of the microstructure highlights that, when the $\mathrm{MgO}$ amount increases from 1 to $5 \mathrm{wt} . \%$, the sintered ceramics have a higher relative density while the mean grain size is smaller (Table 1 and Fig. 12). When doped with 5 wt. $\%$ of $\mathrm{MgO}$, samples made from the attrition-milled $\mathrm{Zr}_{2} \mathrm{O}\left(\mathrm{PO}_{4}\right)_{2}$ powder can be densified up to $99.6 \%$ of the relative density and the grain size maintained between 0.5 and $1.5 \mu \mathrm{m}$. When the unmilled powder is used, relative density is lower $(93.4 \%)$ and the mean grain size bigger $(10-20 \mu \mathrm{m})$. This value is higher than the transition grain size reported by Yamai and Ota and previously explained in this paper [13]. The presence of a lot of microcracks, as shown on Fig. 12-c, was thus expected. If the spark plasma sintering of unmilled powder lead to ceramics with acceptable final relative density, the presence of these microcracks makes these samples unusable as a thermal shock resistant materials. Note that some microcracks are also observed in the sample made with the milled powder doped with 1 wt. $\%$ of $\mathrm{MgO}$. The microcracks are located near the grains with a size value higher than the transition grain size (Fig. 12-b).

Table 1. Sintering conditions, relative density and mean grain size for the five more significant samples.

\begin{tabular}{|c|c|c|c|}
\hline Sample & Sintering conditions & Relative density (\%) & Grain size \\
\hline $\mathrm{Zr}_{2} \mathrm{O}\left(\mathrm{PO}_{4}\right)_{2}$ without additive & $\mathrm{SPS}-1450^{\circ} \mathrm{C}-1 \mathrm{~min}$ & 77.8 & ND \\
\hline $\mathrm{Zr}_{2} \mathrm{O}\left(\mathrm{PO}_{4}\right)_{2}+1$ wt. $\% \mathrm{MgO}$ & $\mathrm{SPS}-1300^{\circ} \mathrm{C}-1 \mathrm{~min}$ & 96.3 & $5-10 \mu \mathrm{m}$ \\
\hline $\mathrm{Zr}_{2} \mathrm{O}\left(\mathrm{PO}_{4}\right)_{2}+3$ wt. $\% \mathrm{MgO}$ & $\mathrm{SPS}-1300^{\circ} \mathrm{C}-1 \mathrm{~min}$ & 98.3 & $3-8 \mu \mathrm{m}$ \\
\hline $\mathrm{Zr}_{2} \mathrm{O}\left(\mathrm{PO}_{4}\right)_{2}+5$ wt. $\% \mathrm{MgO}$ & $\mathrm{SPS}-1300^{\circ} \mathrm{C}-1 \mathrm{~min}$ & 99.6 & $0.5-1.5 \mu \mathrm{m}$ \\
\hline $\begin{array}{l}\text { Unmilled } \mathrm{Zr}_{2} \mathrm{O}\left(\mathrm{PO}_{4}\right)_{2}+5 \text { wt. } \% \\
\mathrm{MgO}\end{array}$ & $\mathrm{SPS}-1300^{\circ} \mathrm{C}-1 \mathrm{~min}$ & 93.4 & $10-20 \mu \mathrm{m}$ \\
\hline $\mathrm{Zr}_{2} \mathrm{O}\left(\mathrm{PO}_{4}\right)_{2}+5$ wt. $\% \mathrm{ZnO}$ & $\begin{array}{l}\text { Conventional sintering } \\
\qquad 1260^{\circ} \mathrm{C}-2 \mathrm{~h}\end{array}$ & 92.0 & $5-20 \mu \mathrm{m}$ \\
\hline
\end{tabular}

Note that samples were sintered at least 2 times each. Results are highly reproductive. 

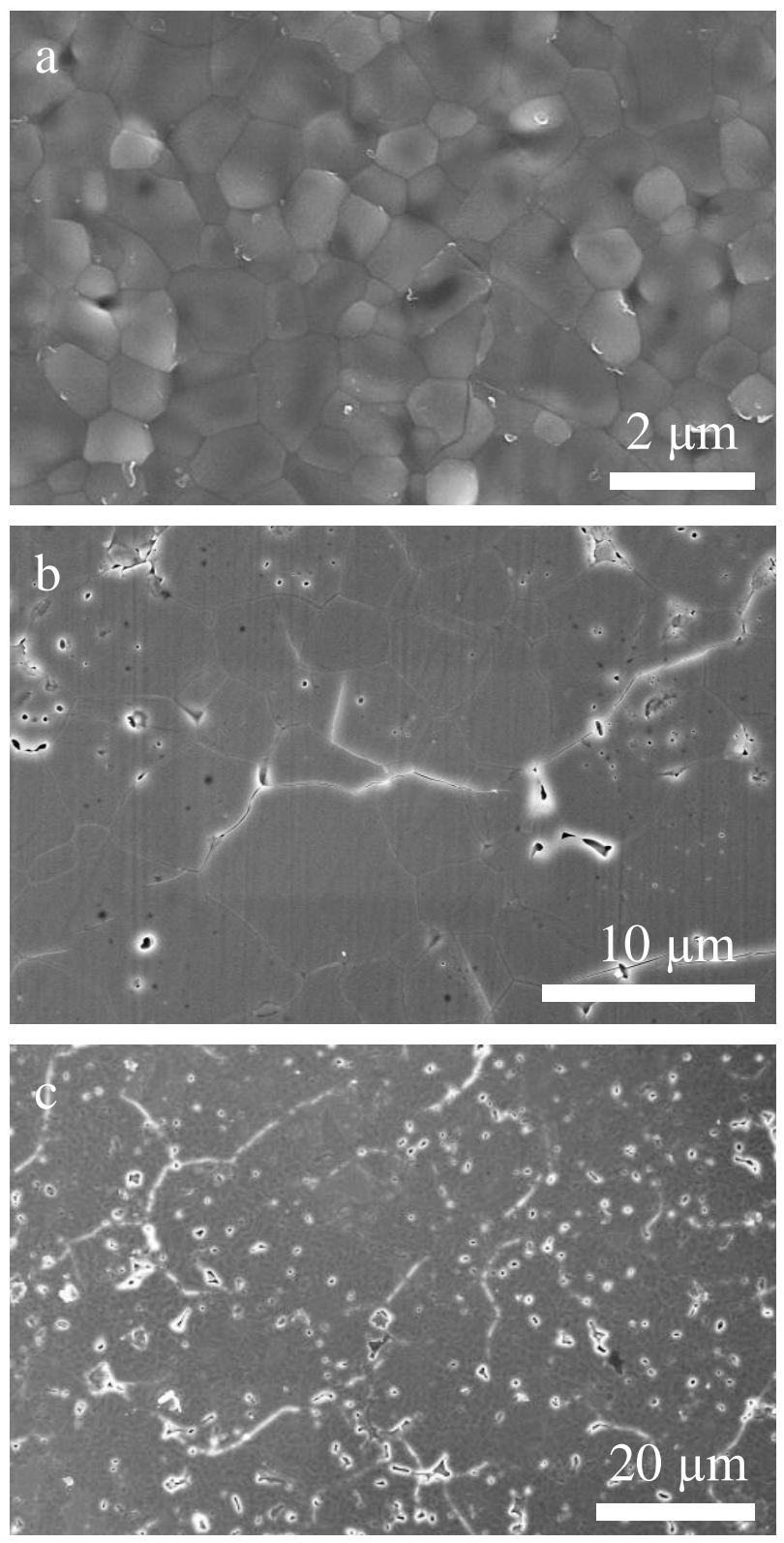

Fig. 12. Microstructure of SPS ZrP milled $+\mathrm{MgO} 5 \% 1300{ }^{\circ} \mathrm{C}(\mathrm{a})$, SPS $\mathrm{ZrP}$ milled $+\mathrm{MgO} 1$ $\% 1300{ }^{\circ} \mathrm{C}(\mathrm{b})$, polished surface of SPS unmilled $\mathrm{ZrP}-\mathrm{MgO} 5 \% 1300{ }^{\circ} \mathrm{C}$

\subsection{Properties}

Changes in thermal conductivity from room temperature to $170{ }^{\circ} \mathrm{C}$ are plotted in Fig. 13 for different ceramic samples. The sample made by conventional sintering with $\mathrm{ZnO}$ as sintering aid exhibits thermal conductivity similar to that published by Omori et al. [21]. When sintered by SPS, thermal conductivity is found to be significantly enhanced, even without sintering 
additive, suggesting that $\mathrm{ZnO}$ has a negative impact on the thermal conductivity. The higher thermal conductivity, i.e. $4.9 \mathrm{~W} \cdot \mathrm{m}^{-1} \cdot \mathrm{K}^{-1}$ at room temperature, is obtained for the ceramic made from attrition-milled powder sintered by SPS with $5 \mathrm{wt} . \% \mathrm{MgO}$. This value is more than twice the values obtained with a conventional sintering and reported in the literature [21]. Thermal conductivity is a little bit lower when unmilled powder is used, which can be explained by the presence of residual microcracks within the sample (Fig. 12).

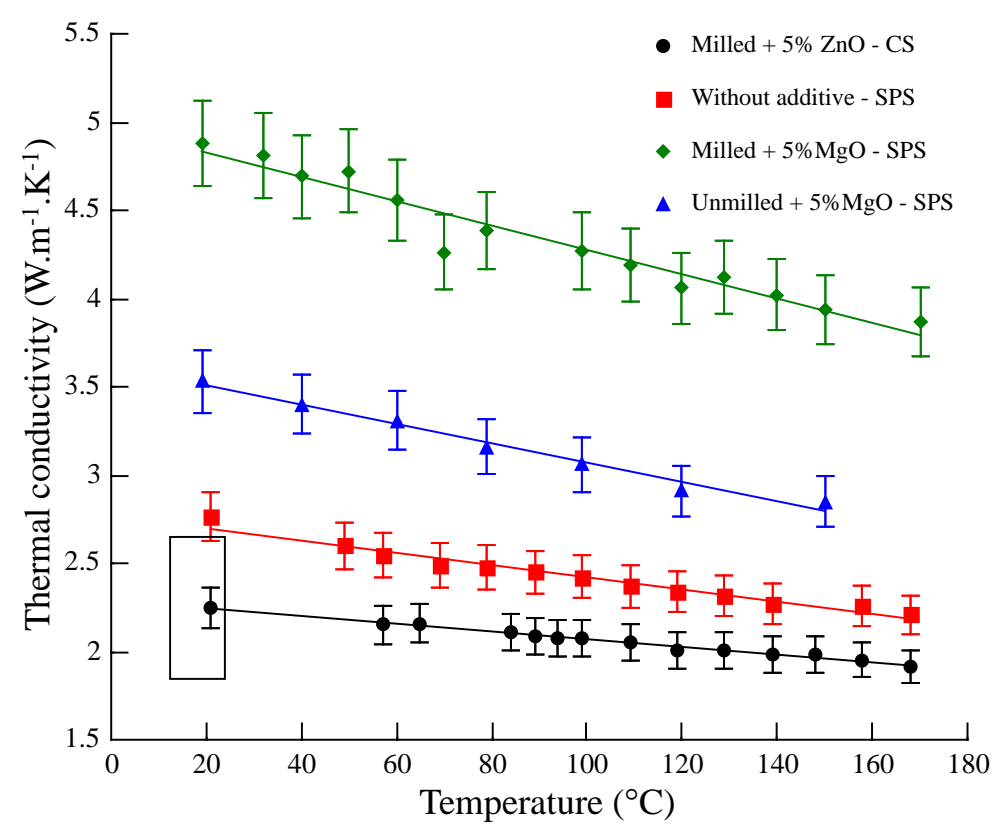

Fig. 13. Thermal conductivity of $\mathrm{Zr}_{2} \mathrm{O}\left(\mathrm{PO}_{4}\right)_{2}$ ceramic samples in the $20-180{ }^{\circ} \mathrm{C}$ temperature range after different sintering conditions (CS: Conventional sintering; SPS: Spark Plasma Sintering). The grey rectangle represents the data from [21].

Hardness was measured by Vickers micro indentation. The effect of $\mathrm{MgO}$ doping level on the hardness of the ceramics sintered by SPS is plotted on Fig. 14. Results show that MgO addition has a positive effect on the mechanical properties of $\mathrm{Zr}_{2} \mathrm{O}\left(\mathrm{PO}_{4}\right)_{2}$ ceramics. Best value is obtained for the ceramic doped with $5 \mathrm{wt} \% \mathrm{MgO}$, thanks to a finer microstructure and a smaller amount of residual microcracks. Combined with an enhanced thermal conductivity, this sample is very promising as a thermal shock resistant material. 


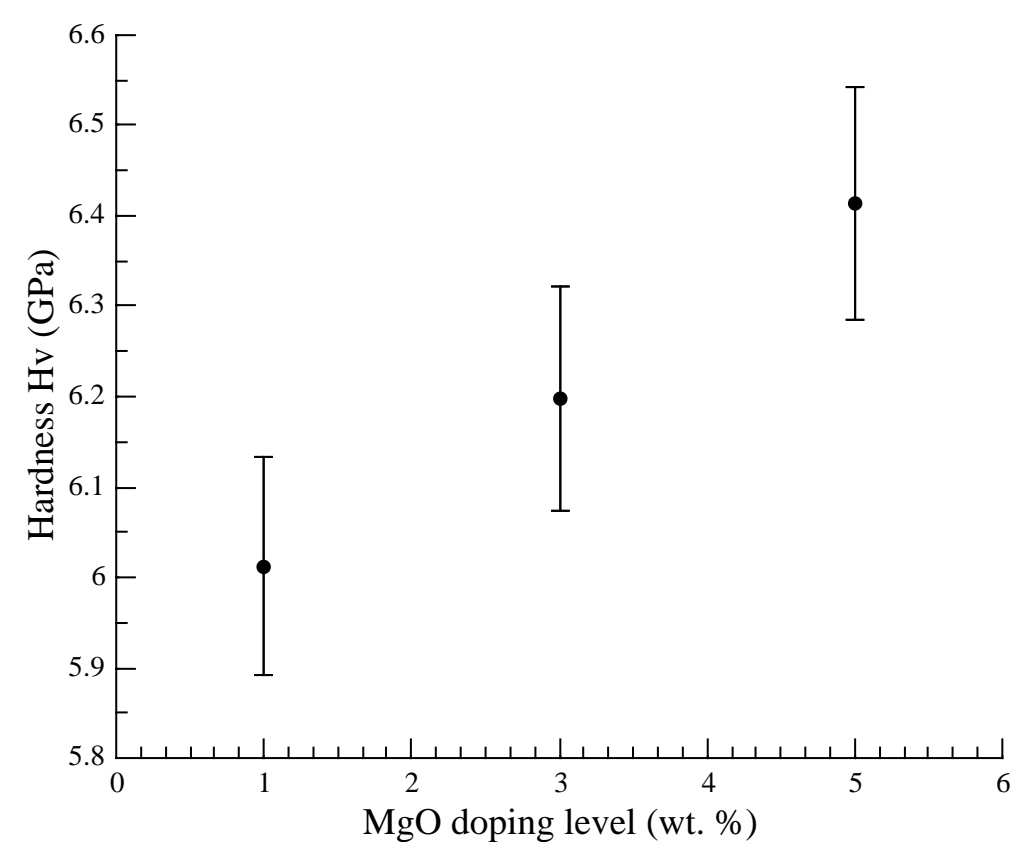

Fig. 14. Vickers hardness of $\mathrm{Zr}_{2} \mathrm{O}\left(\mathrm{PO}_{4}\right)_{2}$ ceramics sintered by SPS vs $\mathrm{MgO}$ doping level

\section{Conclusions}

$\beta-\mathrm{Zr}_{2} \mathrm{O}\left(\mathrm{PO}_{4}\right)_{2}$ ceramics were prepared by conventional sintering and by spark plasma sintering. Results showed that the ceramics do not densify at all by conventional sintering without additive. When doped with 5 wt. \% of $\mathrm{ZnO}$, ceramics can be densified up to $92.5 \%$ of the relative density, but microstructure consist of huge grains that decrease both thermal and mechanical properties. On the other hand, $\beta-\mathrm{Zr}_{2} \mathrm{O}\left(\mathrm{PO}_{4}\right)_{2}$ ceramics with well-controlled density and microstructure were sintered by using the SPS technique on attrition-milled powders with or without additive. When doped with 5 wt. \% of $\mathrm{MgO}$, samples made from the attrition milled $\mathrm{Zr}_{2} \mathrm{O}\left(\mathrm{PO}_{4}\right)_{2}$ powder can be densified up to $99.6 \%$ of the relative density and the grain size maintained between 0.5 and $1.5 \mu \mathrm{m}$. When a smaller amount of dopant is used, relative density is smaller and the grain size bigger. This leads to the presence of numerous microcracks, since $\beta-\mathrm{Zr}_{2} \mathrm{O}\left(\mathrm{PO}_{4}\right)_{2}$ exhibits strong thermal expansion anisotropy. Vickers microhardness and thermal conductivity of sintered ceramics is investigated in relation with 
their microstructure. The main key for achieving the best thermal and mechanical properties is to maintain grain size below the "transition grain size" of around $7 \mu \mathrm{m}$. Thus, improved mechanical and thermal properties were achieved for the sample sintered by SPS with 5\% wt. $\%$ of $\mathrm{MgO}$. This sample is very promising as a thermal shock resistant material.

\section{Acknowledgments}

This work was supported by the French program MATINEX (CNRS-CEA) and by Polytech Paris UPMC. The authors are very grateful to Romain Faye and Laetitia Corde, students of Polytech Paris UPMC and Chimie-ParisTech for their precious help during their training period, and to Mathilde Blondeau for proofreading. SEM-FEG instrumentation was facilited by the IMPC FR2482 (Institut des Matériaux de Paris Centre) and was funded by UPMC, CNRS and by the C'Nano projects of the Région Ile-de-France.

\section{References}

[1] C.M. Sands, R.J. Henderson, H.W. Chandler, Comp Mater Sci, 39 (2007) 862-870.

[2] L. Shen, M. Liu, X. Liu, B. Li, Mater Res Bull, 42 (2007) 2048-2056.

[3] M. Kalantar, G. Fantozzi, Mat Sci Eng A, 472 (2008) 273-280.

[4] Y. Yosida, J Appl Phys, 87 (2000) 3338-3341.

[5] A.W. Sleight, Inorg Chem, 37 (1998) 2854-2860.

[6] G. Wallez, M. Quarton, "Beta-zirconium oxide phosphate and related phases: new mechanisms of ultra low thermal expansion"; pp. 181-196 in Ceramic Materials Research Trends, Ch. 7. Edited by Nova Press, New York, 2007.

[7] G. Wallez, S. Launay, J.-P. Souron, M. Quarton, E. Suard, Chem Mater, 15 (2003) 37933797. 
[8] G. Wallez, D. Bregiroux, M. Quarton, J Solid State Chem, 181 (2008) 1413-1418.

[9] G. Wallez, J.-P. Souron, M. Quarton, Solid State Sci, 8 (2006) 1061-1066.

[10] J. Angelkort, Z. D. Apostolov, Z. A. Jones, S. Letourneau, W. M. Kriven, J Am Ceram Soc, 96 (2013) 1292-1299.

[11] B. A. Bender, T.L. Jessen, S. Browning, Ceram Eng Sci Proc, 16 (1995) 16 613-620.

[12] C. Barreteau, D. Bregiroux, G. Laurent, G. Wallez, Mater Res Bull, 45 (2010) 19962000.

[13] I. Yamai, T. Ota, J Am Ceram Soc, 68 (1985) 273-278.

[14] I. Yamai, T. Ota, J Am Ceram Soc, 70 (1987) 585-590.

[15] N. Poirot, D. Bregiroux, P. Boy, C. Autret-Lambert, P. Belleville, L. Bianchi, Ceram Inter, 41 (2015) 3879-3887.

[16] C. Zhu, J. Lang, N. Ma, Ceram Int, 38 (2012) 6131-6136.

[17] C. Zhu, H. Zhao, W. Fa, X. Yang, Z. Zheng, Ceram Int, 40 (2014) 7467-7472.

[18] S.E. Gustafsson, Rev Sci Instrum, 62 (1991) 797-804.

[19] Y. He, Thermochim Acta, 436 (2005) 122-129.

[20]O.E. Harrison, H.A. McKinstry, F.A. Hummel, J Am Ceram Soc, 37 (1954) 277-280.

[21] M. Omori, K-C. Hsu, S. Tsunekawa, T. Hirai, J Mater Sci, 27 (1992) 408-412. 